\title{
A new species of Polycoelia (Kallymeniaceae, Rhodophyta), P. kurariirapa, from the Three Kings Islands/Manawatāwhi, New Zealand
}

\author{
Roberta D'Archino (10) ${ }^{1}$, Bruce Ngauma ${ }^{2,3}$, Jerry H. Norman ${ }^{2,4}$, and Giuseppe C. Zuccarello (1) $^{5}$ \\ ${ }^{1}$ National Institute of Water and Atmospheric Research Ltd, Private Bag 14-901, Wellington 6241, New Zealand \\ ${ }^{2}$ Ngäti Kuri \\ ${ }^{3} 3$ Times Place, Pukekohe, New Zealand \\ ${ }^{4} 100$ Becroft Drive, Forrest Hill, North Shore, Auckland 0620, New Zealand \\ ${ }^{5}$ School of Biological Sciences, Victoria University of Wellington, PO Box 600, Wellington, New Zealand
}

\begin{abstract}
A new species of Polycoelia, P. kurariirapa, is described from the Three Kings Islands/Manawatāwhi, representing the first record of the genus in New Zealand. Polycoelia includes two species from Australia, P. laciniata (generitype) and P. fastigiata, and one from South Africa, P. harveyana. Polycoelia kurariirapa shares with the two Australian species the characteristic vegetative anatomy of the genus consisting of a single layer of medullary cells surrounded by a cortex of small-celled, anticlinal filaments, and branched thalli. The $r b c L$ phylogenetic analysis confirmed the close, and sister, relationship of $P$. kurariirapa with the Australian taxa, while they were only weakly grouped with $P$. harveyana. This new genus adds to the unique seaweed flora of these islands in northern New Zealand and indicates that this area may harbour even more hidden diversity.
\end{abstract}

\section{ARTICLE HISTORY}

Received 11 July 2019

Accepted 19 December 2019

Published online 04

February 2020

\section{KEYWORDS}

Gigartinales; New species;

Ngāti Kuri; rbcL; Taxonomy

\section{INTRODUCTION}

Recently the family Kallymeniaceae (Gigartinales, Rhodophyta) has been the object of several taxonomic studies, increasing the number of taxa to 42 genera and over 200 species (Guiry \& Guiry 2019). New taxa from Australia and New Zealand have contributed the most to this diversity (e.g. D'Archino et al. 2017, 2018; Saunders et al. 2017). Interestingly, even though both regions are highly diverse, they currently share only a few genera (Stauromenia, Ectophora, and Callophyllis). In New Zealand, studies of the Kallymeniaceae have focused mostly on the taxonomic reassessment of known taxa, resulting in some genera being excluded from the New Zealand algal flora (e.g., Kallymenia (D'Archino et al. 2010), Pugetia (D'Archino et al. 2016), Thamnophyllis (D'Archino et al. 2018; Saunders et al. 2017). Callophyllis is still recognised in the flora of New Zealand, but these species require further study (D'Archino et al. 2017, 2018).

The present study focuses on collections made at Three Kings Islands, hereafter Manawatāwhi, remote uninhabited islands north of North Island of New Zealand. A small red algal epiphyte was collected there that showed some characteristics of Polycoelia.

The genus Polycoelia was considered a monospecific Australian genus with the type species Polycoelia laciniata J. Agardh (1849), until recent molecular investigations (Saunders et al. 2017) resurrected Polycoelia fastigiata Harvey (1859) from Australia, and included a third species, $P$. harveyana (J.Agardh) G. W.Saunders (previously referred to as Pugetia harveyana
J.Agardh), from South Africa. Within the Kallymeniaceae, Polycoelia can be distinguished on the basis of its vegetative anatomy, consisting of a single layer of large thick-walled medullary cells surrounded by a cortex of narrow, small-celled anticlinal filaments (Womersley 1994).

The aim of this study is to describe the collection of Polycoelia from Manawatāwhi. The naming of this species is an outcome of an ongoing collaboration between Ngāti Kuri and taxonomists to document the diversity at Manawatāwhi (Nelson et al. 2019). This partnering in taxonomy acknowledges Ngāti Kuri as kaitiaki (guardians), as Manawatāwhi lies within the Ngāti Kuri rohe (boundaries). Applying a Ngāti Kuri framework to inform the naming of seaweeds has enabled the exchange of knowledge and principles between taxonomists and iwi (tribe).

\section{MATERIAL AND METHODS}

A collection was made by SCUBA diving, consisting of a clump composed of several specimens epiphytic on Rhodymenia australis Sonder sensu Adams (1994). Samples were pressed as vouchers and deposited in the Auckland Museum (AK; Thiers 2019). Collections from WELT of the host were examined, and some unregistered specimens referable to the new taxon were found, including two that were removed and remounted on herbarium paper as vouchers.

Morphological observations were carried out on rehydrated material. Hand-cut sections were either stained with $1 \%$ aniline blue acidified with $1 \% \mathrm{HCl}$ and mounted in $40 \%$ Karo syrup (Karo, Englewood Cliffs, New Jersey, USA), or stained with Wittmann's aceto-iron-haematoxylin-chloral hydrate (Wittmann 
1965). Photomicrographs were taken using an Olympus BX53 microscope (Olympus, Tokyo, Japan) with an SC100 digital camera (Olympus, Münster, Germany).

DNA was extracted from one specimen with a modified CTAB protocol (Zuccarello \& Lokhorst 2005) and the plastidencoded large subunit of the ribulose bisphosphate carboxylase/oxygenase gene $(r b c \mathrm{~L})$ was amplified using the primer combination F145-R898 and F762-R1442 (Kim et al. 2010). PCR products were cleaned using ExoSAP-IT reagent (Affymetrix, Santa Clara, California, USA) and commercially sequenced (Macrogen, Korea). The new sequence was deposited in GenBank (MN091844).

Sequences were assembled and edited in Geneious Prime 2019.1.3 (https://www.geneious.com). MAFFT alignments were implemented in Geneious. The $r b c \mathrm{~L}$ dataset was partitioned by codon. Bayesian inference was performed with MrBayes v3.2 (Ronquist \& Huelsenbeck 2003; Ronquist et al. 2012). Analyses consisted of two independent simultaneous runs of one cold and three incrementally heated chains, and 3 $\times 10^{6}$ generations with sampling every 1000 generations. A burn-in of $5 \times 10^{5}$ generations was used and 25,000 trees were saved to make the consensus tree. ML analyses were implemented using IQ-tree (Trifinopoulos et al. 2016). IQtree was used to select the molecular evolution models (ModelFinder, Kalyaanamoorthy et al. 2017) and construct a maximum-likelihood (ML) tree with 1000 bootstrap replications. Meredithia compaginata G.W.Saunders (KX783123) was used as the outgroup.

\section{RESULTS}

\section{Phylogenetic results}

The $r b c \mathrm{~L}$ dataset consisted of 51 taxa and 1356 base pairs, with 455 bp informative sites. Maximum-likelihood analysis produced a tree (Ln likelihood $=-1350.5305$; Fig. 1) very similar to the Bayesian topology (not shown) and reflecting many of the relationships seen in other studies. Our sample from Manawatāwhi, was in a well-supported clade and sister to the two Australian species of Polycoelia ( $P$. laciniata, $P$. fastigiata). These three species grouped with the South African species ( $P$. harveyana) but without any support in either analysis. The genetic placement, and morphological characters indicated that these specimens are a new species of Polycoelia from New Zealand, and we propose the following new species:

\section{Polycoelia kurariirapa D’Archino, Zuccarello \& Ngāti Kuri sp. nov. \\ Figs $2-16$}

DIAGNOSIs: Thalli epiphytic, flattened, $2.0-4.5 \mathrm{~cm}$ high, subdichotomously branched or irregularly alternate, terminating with truncate or attenuate apices. Thalli composed of a single layer of large medullary cells, surrounded by filaments and a thick cortex of smallcelled anticlinal filaments. Thick cuticle covering the blades. Epidermal cells in surface view in packets. Tetrasporophyte isomorphic bearing cruciate tetrasporangia scattered in the cortex. Carpogonial branch system composed of a lobed supporting cell bearing three elongated subsidiary cells and a single three-celled carpogonial branch. Nonprocarpic, auxiliary cell system consisting of supporting cell and three subsidiary cells. Carposporangia in clusters, surrounded by enveloping filaments and thick pericarp. Cystocarps protruding, non-ostiolate, developing on both sides of the branches.

HOLOTYPE: AK377775, collected 10 April 2013, R. D'Archino, deposited in Auckland War Memorial Museum (AK), $r b c \mathrm{~L}$ (GenBank acc. no. MN091844), Fig. 2.

ISOTYPES: AK377776, Figs 3, 4.

TYPE LOCALITY: $34^{\circ} 10.528^{\prime} \mathrm{S}, 172^{\circ} 02.84^{\prime} \mathrm{E}$, Manawatāwhi/Three Kings Islands, New Zealand; subtidal, collected at 25-26 m depth, epiphyte on stipe of Rhodymenia australis Sonder sensu Adams 1994.

ETYMOLOGY: from Te Reo Māori: kura, meaning red, scarlet, red feather, glow; rīrapa (riirapa), meaning divaricating, to branch out at a wide angle, forked, interlaced; rī meaning to screen, protect, screen off, bind, bond; and rapa meaning adhere, cling to, stick to.

\section{Morphology}

Plants were epiphytic, flattened, $2-4.5 \mathrm{~cm}$ high, attached to the host by a small disc. Axes were sub-dichotomously branched, forking at a wide angle (Figs 2, 3), occasionally with short side branches (Fig. 4), terminating with truncate or attenuate apices (Figs 2-4). Uprights were 2-4 $\mathrm{mm}$ wide throughout, with entire margins and without proliferations. Texture was firm, and dried specimens only partially adhere to paper. Axes were 260-480 $\mu \mathrm{m}$ thick, slightly attenuate at the margins (Fig. 5), consisting of a single layer of medullary cells, 110-(140-160)$210 \mu \mathrm{m}$ wide, surrounded by a cortex of small-celled filaments, 50-90 $\mu \mathrm{m}$ thick, forming anticlinal filaments towards the surface (Fig. 6). Epidermal cells in surface view in apparent packets (Fig. 7) loosely arranged, semi-rounded, 2-3 $\mu \mathrm{m}$ wide. Axes were covered by a hyaline, multi-layered cuticle, 40-60 $\mu \mathrm{m}$ thick (Fig. 8) which stains deeply with aniline blue (Fig. 9).

The carpogonial branch system, 27-35 $\mu \mathrm{m}$ in diam., was composed of a lobed supporting cell bearing a single threecelled carpogonial branch and three subsidiary cells (Fig. 10). The auxiliary cell system was composed of a supporting cell bearing three subsidiary cells (Fig. 11) one cutting off a small cell. Although the auxiliary cell system was similar in shape to the initial stages of the carpogonial branch system, the last could be recognised by the carpogonium and its smaller size. Only a partial fusion cell was observed as the subsidiary cells (Fig. 11, arrowheads) and the bulged supporting cell (Fig. 11 arrow) were still visible. Connecting filaments departing from a subsidiary cell (Fig. 12, arrow) were observed in squashed preparations. Carposporangia developed in clusters surrounded by enveloping filaments forming a thick pericarp (Fig. 13). Cystocarps were protruding, non-ostiolate, and developed on the margins of branches, 400-600 $\mu \mathrm{m}$ in diam. (Figs 14, 15). Tetrasporangia were cruciately divided and scattered in the cortex, 13-16 $\times$ 27-34 $\mu \mathrm{m}$ in size (Fig 16). Gametophyte and tetrasporophyte phases were isomorphic. Males were not observed.

\section{DISCUSSION}

This is the first record of the genus Polycoelia in New Zealand, based on a single collection made at Manawatāwhi. Manawatāwhi includes 13 uninhabited islands, and despite their proximity to the New Zealand mainland (about $55 \mathrm{~km}$ 


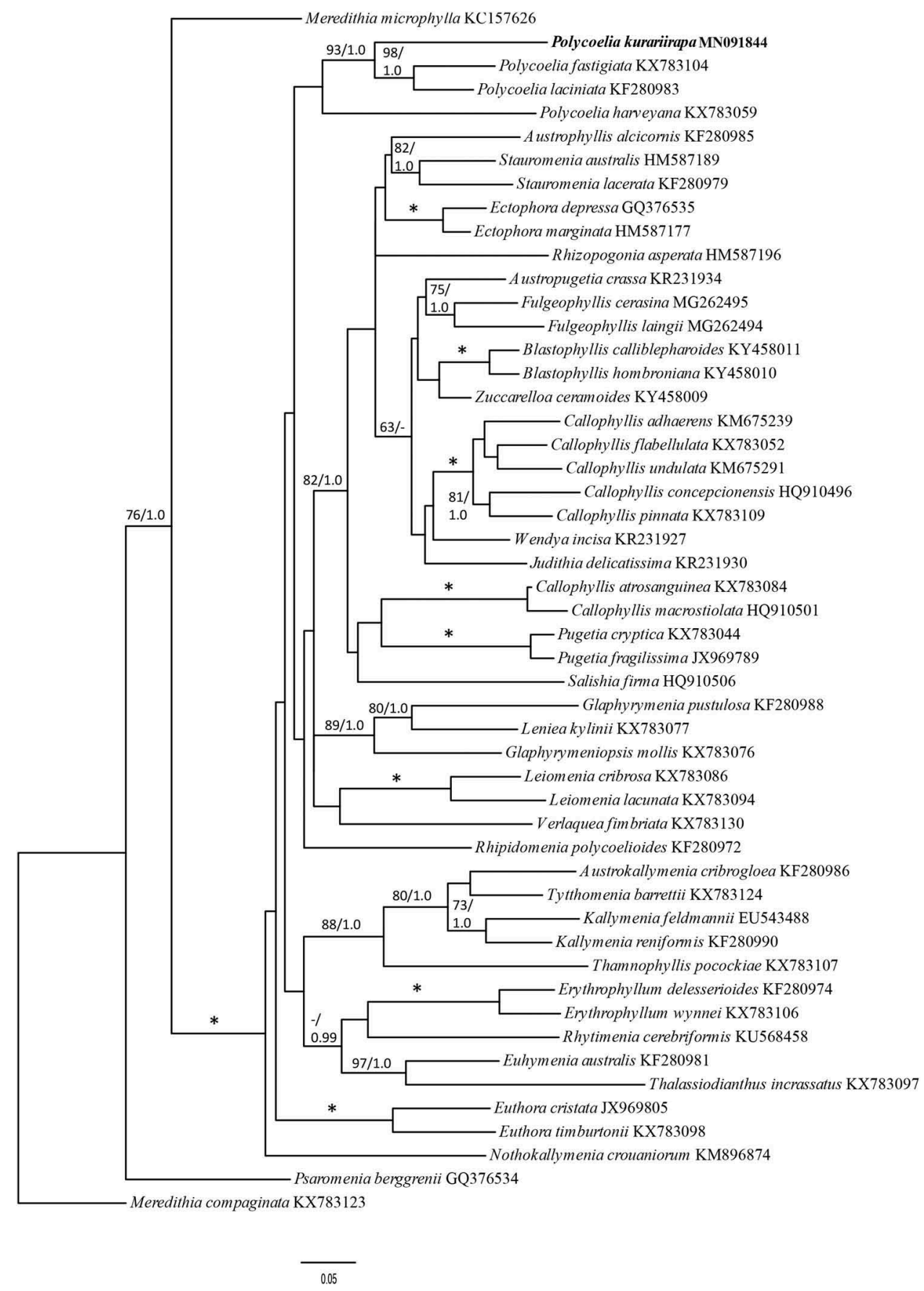

Fig. 1. Maximum-likelihood topology ( $\mathrm{n}$ likelihood $=-13,750.5305$ ) of members of the Kallymeniaceae based on $r b c \mathrm{~L}$ sequence analysis. Genbank accession numbers of downloaded sequences shown. Asterisk $(*)$ denotes $100 \%$ bootstrap percentage (BP) and 1.0 Bayesian posterior probabilities (PP). BP/PP values shown above branches. $\mathrm{BP}<50 \%$ and $\mathrm{PP}<0.9$ not shown.

northwest of Cape Reinga), they host a distinctive algal flora including a number of endemic taxa (Nelson \& D'Archino 2014). The archipelago, volcanic in origin, has been separated for at least 10 million years from the New Zealand mainland (Brook 2003). Several undescribed taxa were collected during the Auckland Museum expedition in 2013, but more collections are necessary to fully document the algal flora of these not easily accessible islands. In addition, the islands are exposed to high energy waves, have steep cliffs and there are no beaches where drift algae can accumulate. Hence, algal collections are carried out mostly by diving or dredging.

The host for Polycoelia kurariirapa was identified as Rhodymenia australis sensu Adams (1994). Rhodymenia australis was transferred to Halopeltis australis (J.Agardh) G.W.Saunders (Saunders \& McDonald 2010), but preliminary molecular data (unpublished) show the Manawatāwhi host is an undescribed species of Rhodymenia, a genus needing further taxonomic assessment in New Zealand. 

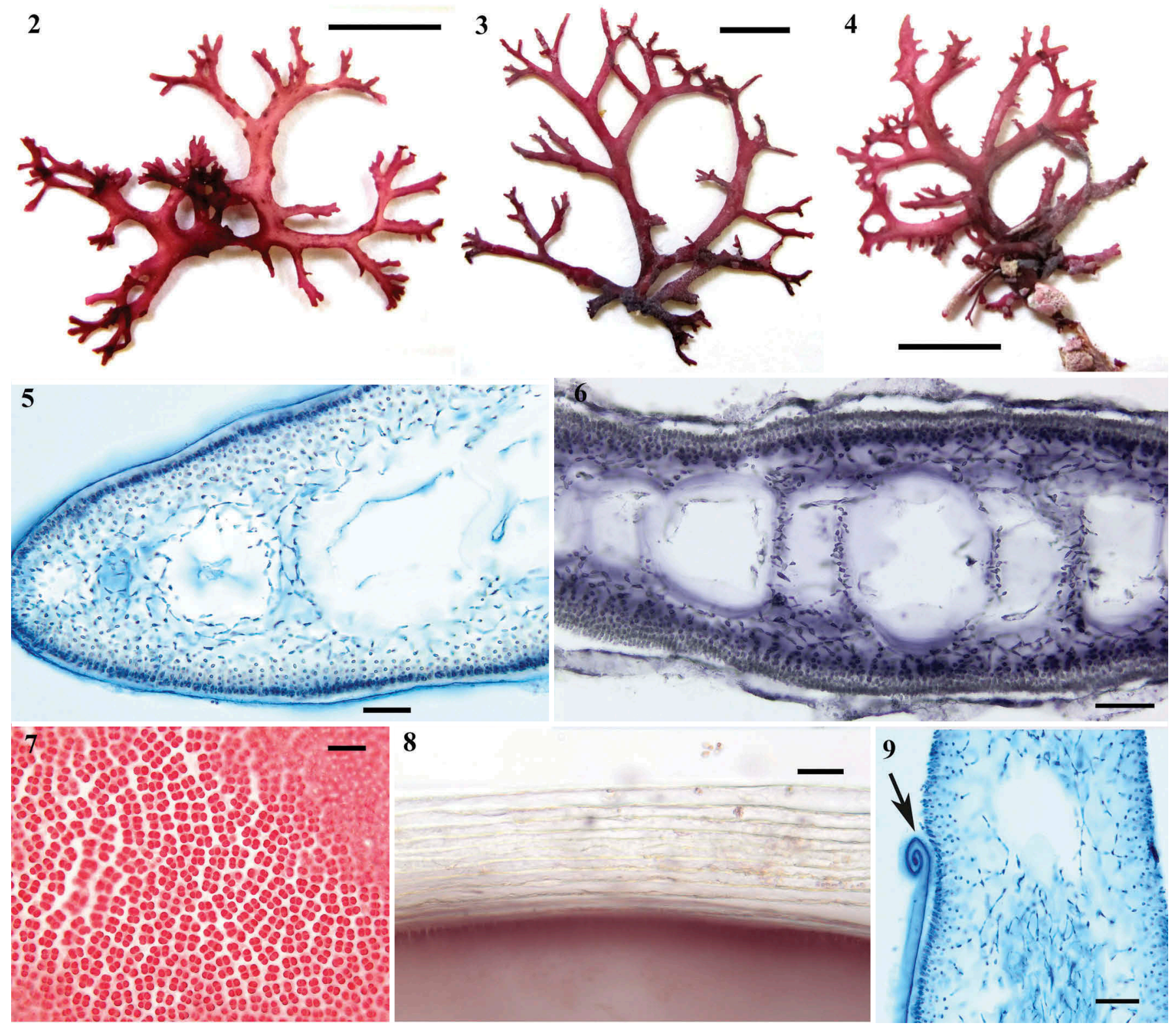

Figs 2-9. Polycoelia kurariirapa sp. nov., habit and vegetative features.

Fig. 2. Holotype of Polycoelia kurariirapa, carposporophyte (AK377775). Scale bar $=2 \mathrm{~cm}$

Fig. 4. Isotypes (AK377776). Vegetative specimen with short lateral branches. Scale bar $=2 \mathrm{~cm}$.

Fig. 3. Isotypes (AK377776). Tetrasporophyte. Scale bar $=2 \mathrm{~cm}$.

Fig. 4. Isotypes (AK377776). Vegetative specimen with short lateral branches. Scale bar $=2 \mathrm{~cm}$.

Fig. 5. Cross section at attenuate margins, stained with aniline blue and showing well-stained cuticle (AK377776). Scale bar $=50 \mu \mathrm{m}$.

Fig. 6. Cross section in the middle of the thallus stained with haematoxylin, showing cortical anticlinal filaments and single-layer of medullary cells (AK377775). Scale bar $=50 \mu \mathrm{m}$.

Fig. 7. Epidermal cells in surface view in apparent packets, unstained (AK377776). Scale bar $=20 \mu \mathrm{m}$.

Fig. 8. Thick, multilayered cuticle in unstained tissue (AK377776). Scale bar $=50 \mu \mathrm{m}$.

Fig. 9. Darkly stained (aniline blue) cuticle rolled up (arrow) (AK377776). Scale bar $=50 \mu \mathrm{m}$.

Polycoelia kurariirapa is strongly related to the two Australian species. It shares the 'unambiguously diagnostic vegetative anatomy' (Womersley 1994) and branched thalli, characters not found in the South African species, P. harveyana, which was related only without bootstrap support to Polycoelia. This South African species needs further study and its placement in Polycoelia should be provisional (Saunders et al. 2017). The reproductive structures of $P$. kurariirapa are similar to the
Australian species (Norris 1957; Womersley \& Norris 1971), and common characteristics include: lobed supporting cell of the carpogonial system, single carpogonial branch, carposporangia developed in clusters, thick pericarp, and non-ostiolate cystocarps. The large fusion cell in carposporophytes observed by Norris (1957) in both Australian species was not observed in $P$. kurariirapa. It is possible that this is due to the limited material we had available for study. In P. kurariirapa, the 

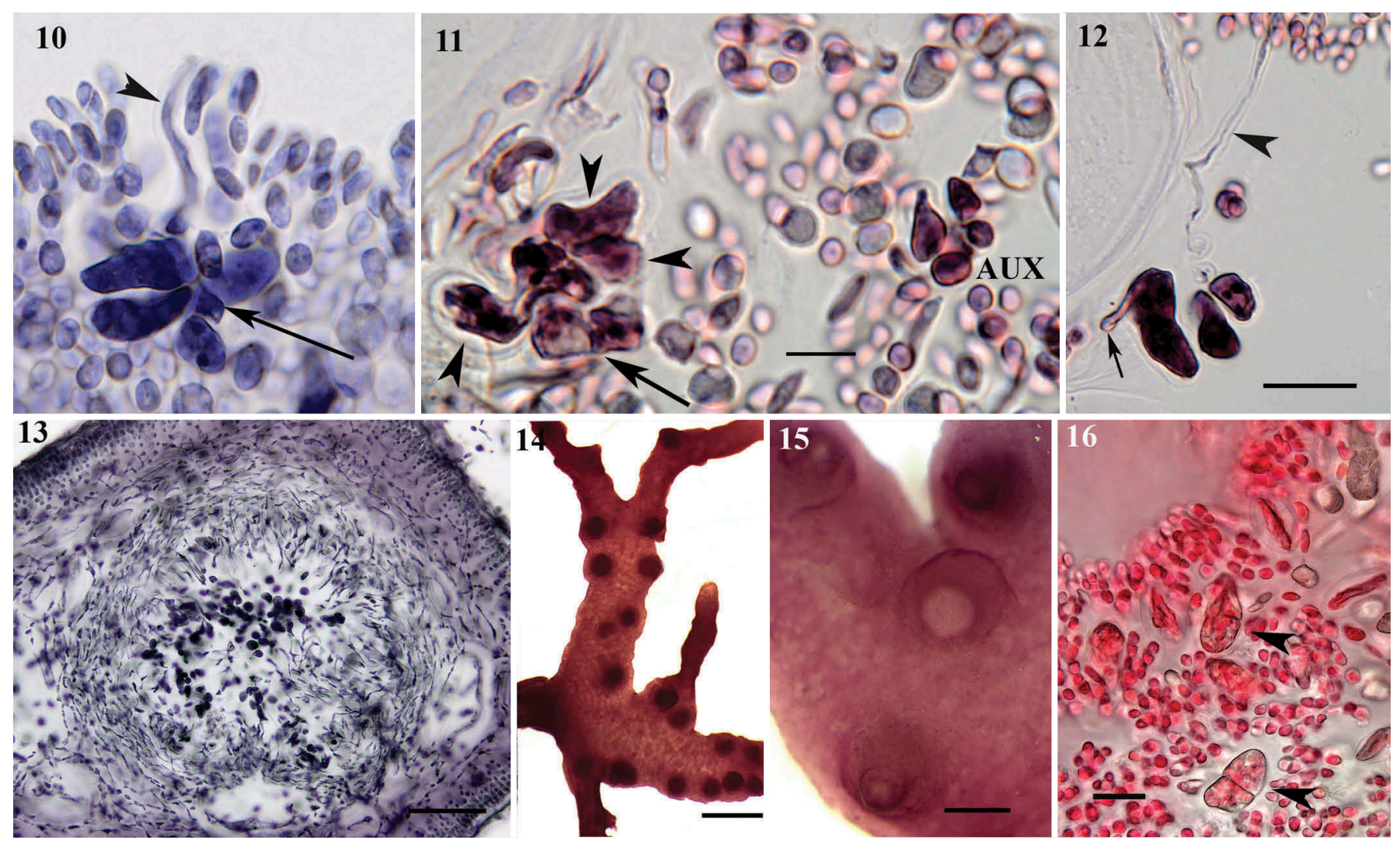

Figs 10-16. Polycoelia kurariirapa sp. nov., reproductive features.

Fig. 10. Monocarpogonial branch system; carpogonium (arrow) and trichogyne (arrowhead). AK377775. Scale bar $=10 \mu \mathrm{m}$.

Fig. 11. Carpogonial branch system (arrow, supporting cell; arrowheads, subsidiary cells) and neighbouring auxiliary cell system (AUX) (AK377775). Scale bar = 10 $\mu \mathrm{m}$.

Fig. 12. Initial of connecting filament (arrow) departing from subsidiary cell. Possible connecting filament in squashed preparation (arrowhead) (AK377775). Scale bar $=10 \mu \mathrm{m}$.

Fig. 13. Cystocarp in cross section. Enveloping filaments seen around developing carposporophyte. Thick pericarp, carposporangia developing in cluster in a nonostiolate cystocarp (AK377775). Scale bar $=50 \mu \mathrm{m}$.

Fig. 14. Non-ostiolate cystocarps developed on margins of branches (AK377775). Scale bar $=2 \mathrm{~mm}$.

Fig. 15. Protruding cystocarps (AK377775). Scale bar $=500 \mu \mathrm{m}$

Fig. 16. Tetrasporangia (arrowheads) scattered in the outer cortex (AK377776). Scale bar $=50 \mu \mathrm{m}$.

auxiliary cell system was rare compared with the numerous carpogonial branch systems observed. In Polycoelia laciniata, Norris (1957) identified a 'group of cells of an accessory character that resemble the carpogonial branch'. In some instances, subsidiary cells of $P$. kurariirapa appeared linked through short cells to darkly stained subcortical cells that might also act as auxiliary cells, but the development of the gonimoblast filaments remains unclear. The involvement of modified vegetative cells in gonimoblast formation has been observed in other genera of Kallymeniaceae: Kallymenia (Hommersand \& Ott 1970), Callophyllis (Lin et al. 2012), Stauromenia (D'Archino et al. 2012), Judithia and Wendya (D'Archino et al. 2016).

While the southwest Pacific Ocean is a hotspot of biodiversity in the Kallymeniaceae, at present New Zealand shares only three genera from the family with Australia Stauromenia, Callophyllis and now, Polycoelia. The genus Ectophora, known from New Zealand, has been reported in Australia (Millar 1993), but this has not been confirmed by molecular investigation (Saunders et al. 2017), so its shared distribution with New Zealand is provisional. This unique, but mostly mutually exclusive, generic diversity may indicate diversification in situ over long periods of time, and requires further study. A new species of Polycoelia, P. kurariirapa, has now been reported and its close relationships to Australian species of the genus is confirmed. Manawatāwhi needs further exploration; and this may be a site for other endemic algae and possibly share further connections to algae in Australia, or other areas of the southwest Pacific.

\section{ACKNOWLEDGEMENTS}

Research was undertaken consistent with Ngāti Kuri's Pou Taiao Environmental Management 2018 and the Living Protocol agreement between the Ngāti Kuri Trust Board and Tāmaki Paenga Hira Auckland Museum. Samples were collected during the Manawatāwhi Three Kings Expedition in 2013 led by the Tâmaki Paenga Hira Auckland Museum. We would like to extend our thanks and gratitude to the Ngāti Kuri Trust Board, Huia Murupaenga, Sandi Ringham, and the Kōtuku Rōpū for their support, guidance and for sharing their mātauranga o Ngāti Kuri. We would like to particularly thank all who participated in the rimurimu meeting in June 2019; the staff of Auckland Museum, particularly Tom Trnski (leader of the expeditions to the islands), Ewen Cameron, and Robert Vennel (Auckland Museum Herbarium) and Anthony Kusabs (WELT). 


\section{FUNDING}

This work was supported by the Strategic Science Investment Fund (SSIF), the National Institute of Water and Atmospheric Research (NIWA).

\section{ORCID}

Roberta D'Archino (D) http://orcid.org/0000-0001-7025-3255

Giuseppe C. Zuccarello (D) http://orcid.org/0000-0003-0028-7227

\section{REFERENCES}

Adams N.M. 1994. Seaweeds of New Zealand. Canterbury University Press, Christchurch. 360 pp.

Agardh J.G. 1849. Algolosgiska bidrag. Öfversigt af Kongl. VetenskapsAdademiens Förhandlingar, Stockholm 6: 79-89.

Brook F. 2003. Three Kings Islands. In: The living reef: the ecology of New Zealand's rocky reefs (Ed. by N. Andrew \& M. Francis), pp. 202-209. Craig Potton Publishing, Nelson.

D’Archino R., Lin S.-M., Gabrielson P.W. \& Zuccarello G.C. 2016. Why one species in New Zealand, Pugetia delicatissima (Kallymeniaceae, Rhodophyta), should become two new genera, Judithia gen. nov. and Wendya gen. nov. European Journal of Phycology 51: 83-98. DOI:10.1080/09670262.2015.1104557.

D'Archino R., Lin S.-M. \& Zuccarello G.C. 2018. Fulgeophyllis (Kallymeniaceae, Gigartinales), a new genus to accommodate two New Zealand species. Phycologia 57: 422-431. DOI:10.2216/17-120.1.

D’Archino R., Nelson W.A. \& Sutherland J.E. 2017. Neither Callophyllis nor Gelidium: Blastophyllis gen. nov. and Zuccarelloa gen. nov. (Kallymeniaceae, Rhodophyta) for three New Zealand species. Phycologia 56: 549-560. DOI:10.2216/16-115.1.

D'Archino R., Nelson W.A. \& Zuccarello G.C. 2010. Psaromenia (Kallymeniaceae, Rhodophyta): a new genus for Kallymenia berggrenii. Phycologia 49: 73-85. DOI:10.2216/08-29.1.

D'Archino R., Nelson W.A. \& Zuccarello G.C. 2012. Stauromenia australis, a new genus and species in the family Kallymeniaceae (Rhodophyta) from southern New Zealand. Phycologia 51: 451-460. DOI:10.2216/11-87.1.

Guiry M.D. \& Guiry G.M. 2019. AlgaeBase. World-wide electronic publication, National University of Ireland, Galway. http://www.algaebase. org; searched on 06 June 2019.

Hommersand M.H. \& Ott D.W. 1970. Development of the carposporophyte of Kallymenia reniformis (Turner) J. Agardh. Journal of Phycology 6: 322-331.

Kalyaanamoorthy S., Minh B.Q., Wong T.K.F., von Haeseler A. \& Jermiin L. S. 2017. ModelFinder: fast model selection for accurate phylogenetic estimates. Nature Methods 14: 587-589. DOI:10.1038/nmeth.4285.

Kim M.S., Kim S.Y. \& Nelson W.A. 2010. Symphyocladia lithophila sp. nov. (Rhodomelaceae, Ceramiales), a new Korean red algal species based on morphology and $r b c \mathrm{~L}$ sequences. Botanica Marina 53: 233-241. DOI:10.1515/BOT.2010.031.

Lin S.-M., D'Archino R. \& Hommersand M.H. 2012. A new method of cystocarp development in the red algal genus Callophyllis
(Kallymeniaceae) from Chile. Journal of Phycology 48: 784-792. DOI:10.1111/j.1529-8817.2012.01151.x.

Millar A.J.K. 1993. The red algal genus Callophyllis Kützing (Kallymeniaceae, Gigartinales) from eastern mainland Australia, with notes on the genus Ectophora J.Agardh. Australian Systematic Botany 6: 321-334. DOI:10.1071/SB9930321.

Nelson W.A. \& D'Archino R. 2014. Three new macroalgae from the Three Kings Islands New Zealand including the first southern Pacific Ocean record of the Furcellariaceae (Rhodophyta). Phycologia 53: 602-613. DOI:10.2216/14-60R1.1.

Nelson W.A., Sutherland J.E., Ringham S. \& Murupaenga H. 2019. Dictyota korowai sp. nov. (Dictyotales, Phaeophyceae) from Manawatāwhi/Three Kings Islands, northern New Zealand, previously confused with Dictyota intermedia. Phycologia 58: 433-442. DOI:10.1080/00318884.2019.1625256.

Norris R.E. 1957. Morphological studies on the Kallymeniaceae. University of California Publications in Botany 28: 251-333.

Ronquist F. \& Huelsenbeck J.P. 2003. MrBayes 3: Bayesian phylogenetic inference under mixed models. Bioinformatics 17: 1572-1574. DOI:10.1093/bioinformatics/btg180.

Ronquist F., Teslenko M., van der Mark P., Ayres D.L., Darling A., Hohna S., Larget B., Liu L., Suchard M.A. \& Huelsenbeck J.P. 2012. MrBayes 3.2: efficient Bayesian phylogenetic inference and model choice across a large model space. Systematic Biology 61: 539-542. DOI: 10.1093/sysbio/sys029.

Saunders G.W., Huisman J.M., Vergés A., Kraft G.T. \& Le Gall L. 2017. Phylogenetic analyses support recognition of ten new genera, ten new species and 16 new combinations in the family Kallymeniaceae (Gigartinales, Rhodophyta). Cryptogamie Algologie 38: 79-132. DOI:10.7872/crya/v38.iss2.2017.79.

Saunders G.W. \& McDonald B. 2010. DNA barcoding reveals multiple overlooked Australian species of the red algal order Rhodymeniales (Florideophyceae), with resurrection of Halopeltis J. Agardh and description of Pseudohalopeltis gen. nov. Botany 88: 639-667. DOI:10.1139/B10-038.

Thiers B. 2019. [continuously updated]. Index Herbariorum: a global directory of public herbaria and associated staff. New York Botanical Garden's Virtual Herbarium. http://sweetgum.nybg.org/science/ih/.

Trifinopoulos J., Nguyen L.-T., von Haesele A. \& Minh B.Q. 2016. W-IQTREE: a fast-online phylogenetic tool for maximum likelihood analysis. Nucleic Acids Research 44: W232-W235. DOI: 10.1093/nar/gkw256.

Wittmann W. 1965. Aceto-iron-haematoxylin-chloral hydrate for chromosome staining. Stain Technology 40: 161-164. DOI:10.3109/ 10520296509116398.

Womersley H.B.S. 1994. The marine benthic flora of southern Australia - Part IIIA - Bangiophyceae and Florideophyceae (Acrochaetiales, Nemaliales, Gelidiales, Hildenbrandiales and Gigartinales sensu lato). Australian Biological Resources Study, Canberra, Australia. 508 pp.

Womersley H.B.S. \& Norris R.E. 1971. The morphology and taxonomy of Australian Kallymeniaceae (Rhodophyta). Australian Journal of Botany (suppl.2): 1-62

Zuccarello G.C. \& Lokhorst G. 2005. Molecular phylogeny of the genus Tribonema (Xanthophyceae) using $r b c \mathrm{~L}$ gene sequence data: monophyly of morphologically simple algal species. Phycologia 44: 384-392. DOI:10.2216/0031-8884(2005)44[384: MPOTGT]2.0.CO;2. 